\title{
The Value of Morphologic Study (MRI) of the Median Nerve in Stadialization and Treatment of the Carpal Tunnel Syndrome
}

\author{
Florin Gabriel PANCULESCU', Raluca STEFANESCU², Ion BORDEIANU', Iulian Catalin BRATU³
}

\begin{abstract}
Carpal tunnel syndrome is a sensitive neuropathy of the upper limb caused by chronic compression of the median nerve.

The presented study focused on highlighting the value of morphological changes of the median nerve - shown by $\mathrm{MRI}$ in the management of carpal tunnel syndrome.

The study group included 23 patients, adults, treated in the Plastic Surgery Clinic of the County Emergency Clinical Hospital in Constanta - prospective study.

Magnetic resonance imaging allowed accurate measurement of the median nerve diameter and showed significant decreases in most cases, which suggested an advanced stage of the disease - morphological changes being corroborated with clinical ones.

This imagistic investigation opens a new way in establishing the surgical indication, which is required in case of reduction of the nerve diameter by at least $1.5 \mathrm{~mm}$ at the site of compression.

The criterion of diameter decrease can be a benchmark in order to establish a therapeutic algorithm in carpal tunnel syndrome.
\end{abstract}

Keywords: carpal tunnel syndrome, magnetic resonance imaging, median nerve, morphology.

\section{Rezumat}

Sindromul de tunel carpian este o neuropatie senzitivă a membrului superior cauzată de compresiunea cronică a nervului median.

Studiul prezentat s-a concentrat pe evidențierea valorii modificărilor morfologice ale nervului median - demonstrate de IRM în managementul sindromului de tunel carpian.

Lotul de studiu a inclus 23 de pacienți, adulți, tratați în Clinica de Chirurgie Plastică a Spitalului Clinic Județean de Urgență din Constanța - studiu prospectiv.

Imagistica prin rezonanță magnetică a permis măsurarea precisă a diametrului nervului median și a prezentat scăderi semnificative în majoritatea cazurilor, ceea ce sugerează un stadiu avansat al bolii modificările morfologice fiind coroborate cu cele clinice.

Această investigație imagistică deschide o nouă cale în stabilirea indicației chirurgicale, care se impune în cazul reducerii diametrului nervului cu cel puțin 1,5 mm la locul compresiunii.

Criteriul scăderii diametrului poate fı un etalon pentru stabilirea unui algoritm terapeutic în sindromul de tunel carpian.

Cuvinte-cheie: sindrom de tunel carpian, imagistică prin rezonanță magnetică, nervul median, morfologie.

'Faculty of Medicine, „Ovidius" University, Constanta, Romania 2 "Sf. Apostol Andrei" Emergency County Hospital, Constanta, Romania

${ }^{3}$ Faculty of Pharmacy, „Ovidius" University, Constanta, Romania
Corresponding author:

Florin Gabriel PANCULESCU, 61 Merisor Street, Constanta, Romania.

E-mail: gabriel.panculescu@yahoo.ro 


\section{BACKGROUND}

The carpal tunnel syndrome is a sensitive neuropathy of the upper limb, which occurs through chronic compression of the median nerve, an action that causes morphological (anatomical) changes with clinical and paraclinical / imaging resonance.

Nerve compression has a great impact on nerve integrity, sometimes irreversible, even complete nerve sections are observed, which require a clear stage diagnosis, established as soon as possible with an appropriate treatment ${ }^{1,2}$.

The studied group consists of 23 patients, adults, treated in the Plastic Surgery Department of the County Emergency Hospital in Constanţa. Enrollment in the study group was done in compliance with clear pre-established inclusion / exclusion criteria.

The morphological study method used in this study is represented by magnetic resonance imaging, given its fidelity and the examined area was at least 12 centimeters, comprising the lower third of the arm and upper half of the palm.

After Sunderland classification, approximately 80\% of patients had grade IV or $\mathrm{V}$ lesions requiring surgical treatment ${ }^{3}$.

\section{INTRODUCTION}

Locally, the pathophysiology of carpal tunnel syndrome results from the game of two variables: increasing the volume of the carpal tunnel content and / or reducing the capacity of the container.

However, the chronic compression of the median nerve must be clearly differentiated from other suffering of the peripheral nerves, caused by physiological or pathophysiological conditions.

In recent decades, the incidence of the disease has increased steadily, which can be explained on the one hand by the increase in life expectancy and on the other hand by the increasing incidence of associated comorbidities. An alarm signal must be raised regarding nervous distress, which requires an early diagnosis and appropriate treatment ${ }^{4-6}$.

In order to establish the most correct and effective treatment, the morphology of the median nerve must be investigated, as its integrity dictates the patient's clinical condition and the therapeutic interventions he needs.

The staging of chronic nerve compression performed on objective criteria - morphological - helps the clinician in choosing the correct treatment and corresponding to each evolutionary stage of the disease ${ }^{3,5}$.

\section{HISTORY}

The first cases of carpal tunnel syndrome were reported in 1854 by James Paget but those who noted for the first time in history the association between anterior carpal ligament pathology and median nerve compression were Pierre Marie and Charles Foix in 1913 and in 1914 , the association of nerve compression with tenor muscle atrophy has been described.

In 1938, F.P. Moersch introduced the phrase „carpal tunnel syndrome".

The second half of the twentieth century included numerous case studies that had the role of discovering the etiopathogenesis and treatment of carpal tunnel syndrome, in order to diagnose as accurately as possible the evolutionary stage of the disease and the application of the recommended therapeutic sanction (indicated) ${ }^{2}$.

\section{MATERIAL AND METHOD}

In order to evaluate the importance of the median nerve morphology in the management of carpal tunnel syndrome, we performed a prospective study on a group of 23 patients who presented to the Plastic Surgery service of Constanta County Emergency Clinical Hospital, with the diagnosis of carpal tunnel, in the surgical phase.

The morphology of the median nerve and that of the structures in its vicinity were studied with the help of magnetic resonance imaging, a study that provided anatomical details superior to any other exploration ${ }^{7-12}$.

The study was carried out over a period of 18 months, respectively 01.04.2019 - 30.09.2020 and for the realization of the study group we pre-established inclusion / exclusion criteria, in order to benefit from the most scientifically conclusive results.

Inclusion in the study was not restrictive, comprising patients of both sexes, adults and regardless of background. Also, patients with various associated pathologies were enrolled, following at the same time their possible correlations with nerve compression as well as idiopathic carpal tunnel syndromes. Noncooperating patients and those who were not present at the pre-established regular medical check-ups were not enrolled.

The main objective of the study was to establish a direct (mathematical) relationship between the 
reduction of the median nerve diameter, following compression (highlighted by MRI) and the evolutionary stage of carpal tunnel syndrome $e^{7,11-15}$.

\section{RESULTS}

The study group included a total of 23 patients, of both sexes, aged between 37 and 68 years, from rural and urban areas, with primary, secondary and university studies.

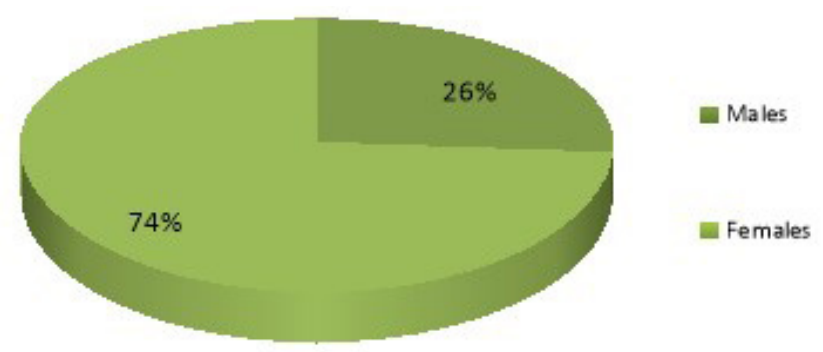

Figure 1. Distribution by sex (6 males, 17 females)

The group was represented by a larger number of women, being well known clear preponderance of females in the development of carpal tunnel syndrome but also increased compliance with investigations against males $^{3}$.

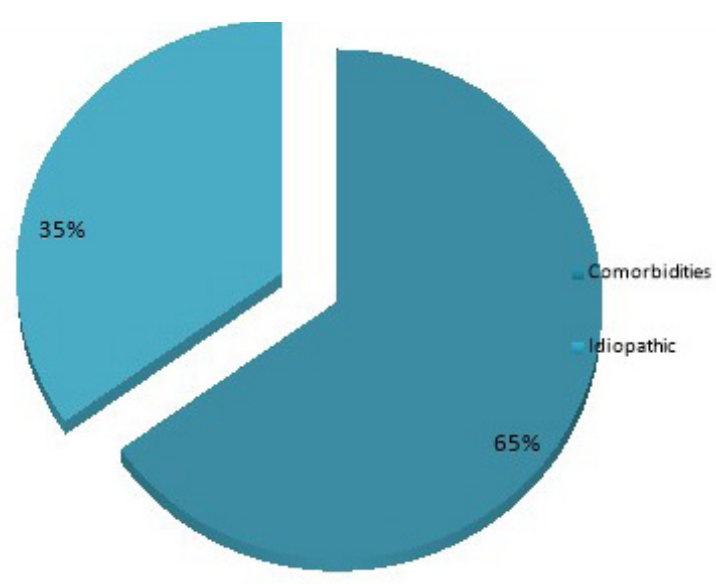

Figure 2. The ratio between patients associated with other pathologies and patients who developed idiopathic carpal tunnel syndrome (15 patients with comorbidities, 8 patients with idiopathic syndrome).

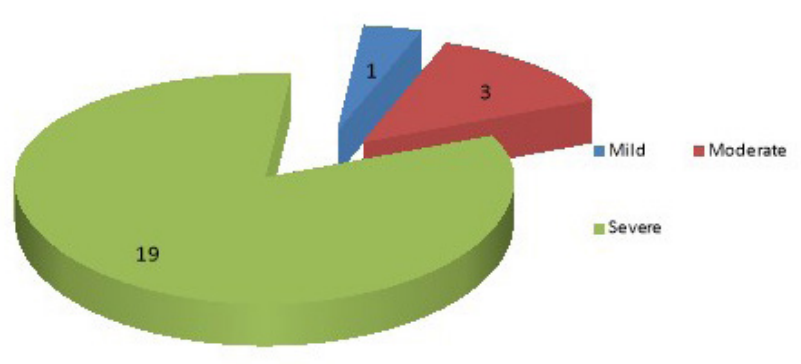

Figure 3. Distribution of patients according to the stage of nerve damage

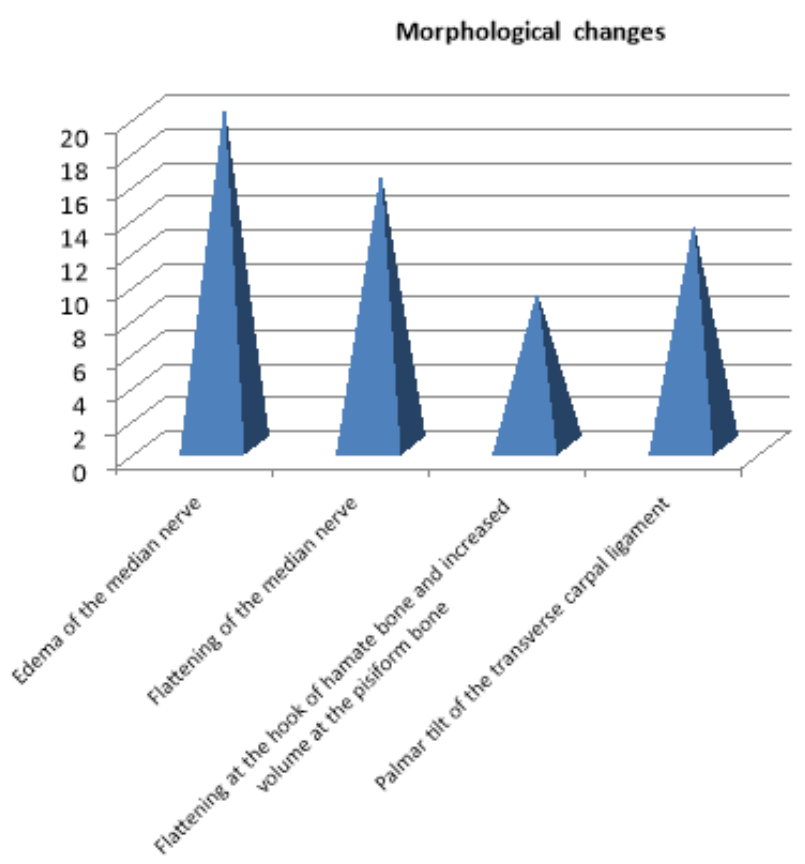

Figure 4. Incidence of morphological changes typical of carpal tunnel syndrome

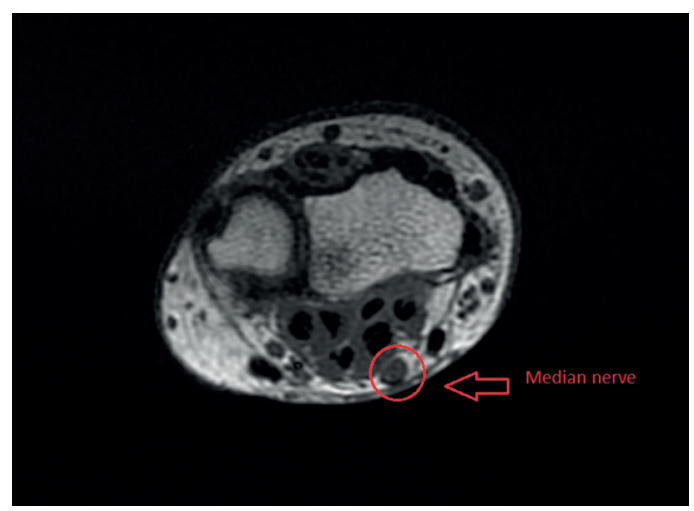

Figure 5. MRI examination, S.L. (M, 62), suggestive aspect for carpal tunnel syndrome, intermediate stage - narrowing of the median nerve by $1.3 \mathrm{~mm}$ 


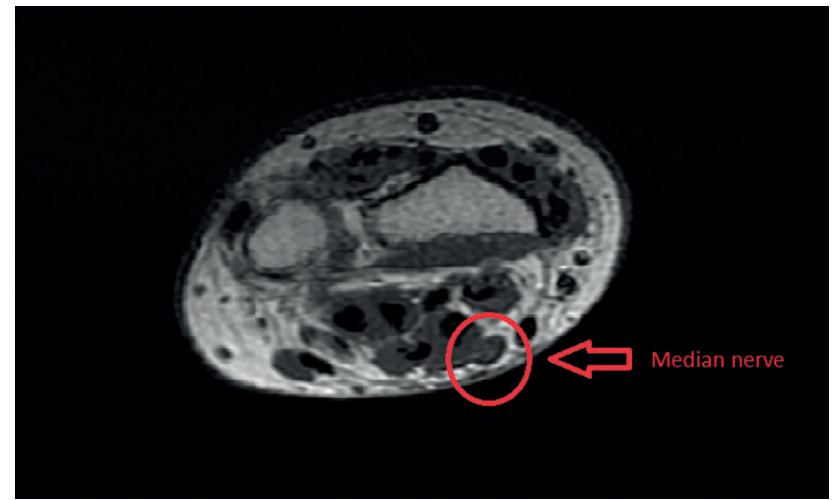

Figure 6. MRI examination, M.V. (F, 57), suggestive aspect for carpal tunnel syndrome, advanced stage - narrowing of the median nerve by $1.8 \mathrm{~mm}$

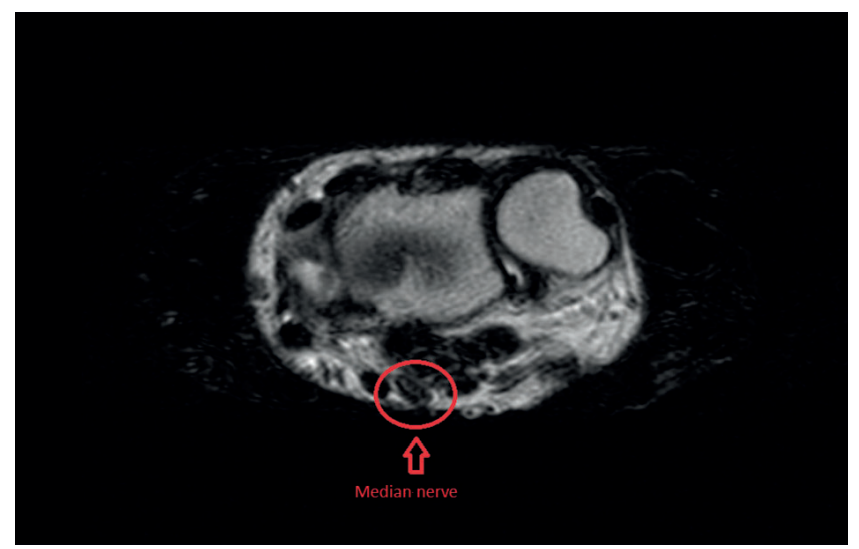

Figure 7. MRI examination, U.M. (F, 51), suggestive aspect for advanced carpal tunnel syndrome - narrowing of the median nerve by $2.2 \mathrm{~mm}$

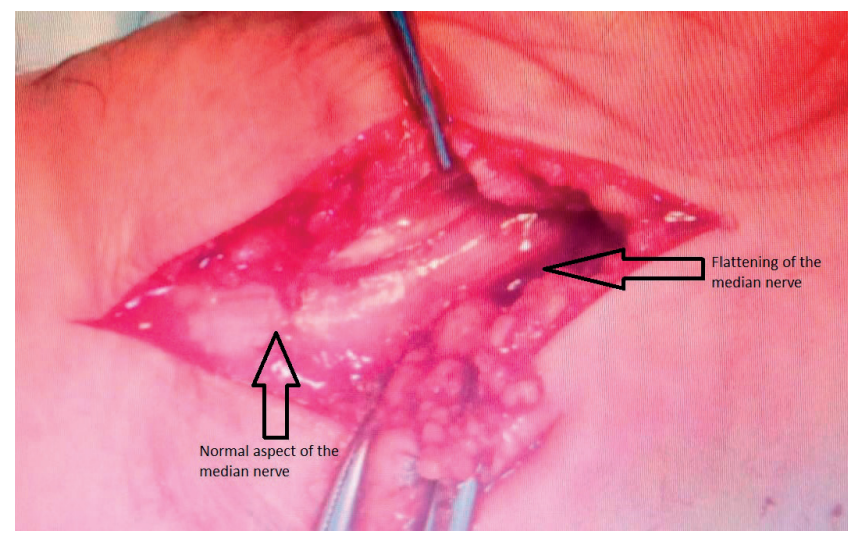

Figure 7. Intraoperative aspect - narrowed median nerve - the concordance of MRI results found and intraoperatively

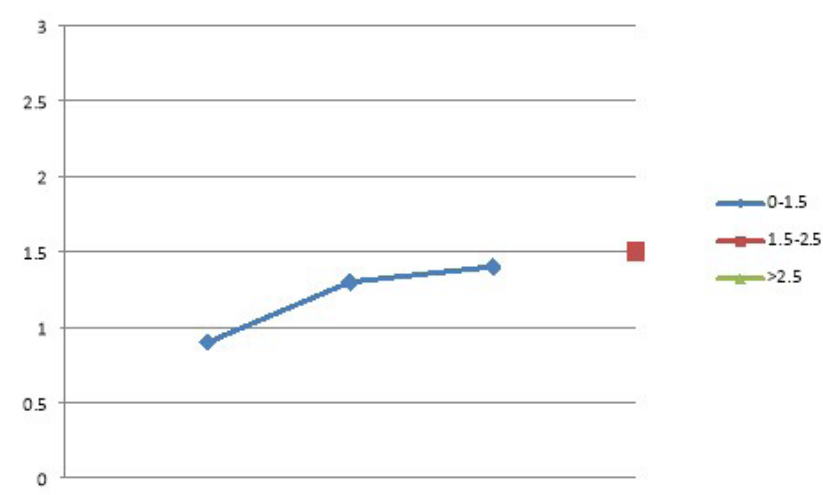

Figure 9. Reduction in diameter of the median nerve at the site of compression, for each patient in the study group.

\section{DISCUSSIONS}

Magnetic resonance imaging illustrated in the present study important morphological changes in the carpal tunnel. The transverse ligament of the carpus tends to tilt palmar and thus induces significant mechanical pressure on the median nerve.

Locally, secondary to chronic compression, nerve inflammation with edema occurs, which maintains and aggravates the lysis of the median nerve.

The pressure exerted by the transverse ligament of the carpus, which often recognizes a marked hypertrophy, or even a palmar inclination, leads to flattening of the median nerve (reduction in diameter), affecting nerve conduction. This sign, visible with the help of magnetic resonance imaging, establishes the evolutionary stage and indication of the surgical intervention ${ }^{6,9,13-15}$.

Approximately $80 \%$ of enrolled patients had morphological changes in the median nerve suggesting advanced carpal tunnel syndrome.

In the present study, patients with a diameter of less than $6 \mathrm{~mm}$ of the median nerve (reduction between 1.5 and $2.5 \mathrm{~mm}$ ) were diagnosed with advanced carpal tunnel syndrome and treated surgically, clearly showing nerve damage by significant morphological changes , also found intraoperatively.

In order to establish a diagnostic (staging) and therapeutic algorithm, we established that a reduction in diameter of the median nerve in the compression area with a value greater than $1.5 \mathrm{~mm}$, can be considered as a benchmark for classification in stage III (surgical) evolutionary and the statistical processing of the obtained data showed the following incidence: 19 cases 
with a diameter reduction between 1.5 and $2.5 \mathrm{~mm}$ and one case with a reduction of $2.6 \mathrm{~mm}$.

\section{CONCLUSIONS}

- Establishing the stage of the disease and the morphology of the carpal tunnel has a crucial role in establishing a successful treatment in compressive syndrome.

- The possibility of measuring the size of the median nerve offers a new perspective in the staging and management of the disease.

- The morphology of the median nerve undergoes clear changes, specific for each stage of carpal tunnel syndrome.

- The present study reveals the superiority of magnetic resonance imaging in objectifying the nerve lesion and establishing the evolutionary stage of the disease and thus the corresponding therapeutic sanction.
- We appreciate that based on the criteria adopted in this study on reducing the diameter of the median nerve, at the site of compression, they can be used to achieve a diagnostic and treatment algorithm.

Compliance with ethics requirements: The authors declare no conflict of interest regarding this article. The authors declare that all the procedures and experiments of this study respect the ethical standards in the Helsinki Declaration of 1975, as revised in 2008(5) and the national law. Informed consent was obtained from the patient described in the clinical case and his parents.

\section{References}

1. Rigoard P. Atlas of Anatomy of the Peripheral Nerves: The Nerves of the Limbs. Student Ed, Springer, 2017. https://doi.org/ 10.1007/978-3-319-43089-8

2. Tubbs RS, Rizk E, Shoja MM, Loukas M, Barbaro N, Spinner RJ. Nerves and Nerve Injuries - Vol 1: History, Embryology, Anatomy, Imaging, and Diagnostics. 1st ed, 2015. https://doi.org/10.1016/ b978-0-12-410390-0.00005-6

3. Durham CO, VanRavenstein K. It's all in the wrist: diagnosis and management of carpal tunnel syndrome. OrthopNurs. 2017. https://doi.org/10.1097/nor.0000000000000390

4. Mackinnon SE. Pathophysiology of nerve compression. Hand clin, 2002. https://doi.org/10.1016/s0749-0712(01)00012-9

5. Annina B Schmid, Jeremy DP Bland, Manzoor A Bhat, David LH Bennett. The relationship of nerve fibre pathology to sensory function in entrapment neuropathy. Brain, Volume 137, Issue 12, December 2014, Pages 3186-3199, https://doi.org/10.1093/ brain/awu288

6. Moutasem S Aboonq. Pathophysiology of carpal tunnel syndrome. Neurosciences (Riyadh), 2015 Jan, 20(1): 4-9. PMID: 25630774, PMCID: PMC4727604

7. Tamara L Marquardt, Joseph NGabra, Peter J Evans, William H Seitz Jr, Zong-Ming Li. Thickness and Stiffness Adaptations of the Transverse Carpal Ligament Associated with Carpal Tunnel Syndrome. J Musculoskelet Res, 2016 Dec. https://doi: 10.1142/ S0218957716500196 PMID: 28824216

8. Gaurav M Kasundra, IshaSood, Amita N Bhargava, Bharat Bhushan, KirtiRana, HemantJangid, KhicharShubhkaran, Guruprasad S Pujar. Carpal tunnel syndrome: Analyzing efficacy and utility of clinical tests and various diagnostic modalities. J Neurosci Rural Pract, 2015 Oct-Dec. doi: 10.4103/09763147.169867, PMID: 26752893

9. Lluch A L. Thickening of the synovium of the digital flexor tendons: cause or consequence of the carpal tunnel syndrome? $J$ Hand Surg [Br] 1992. PMID: 1588206 DOI: 10.1016/02667681(92)90091-f

10. Menorca RM, Fussell TS, Elfar JC. Nerve physiology: mechanism of injury and recovery. Hand Clin. 2013, Aug 29, (3):317-30. doi: 10.1016/j.hcl.2013.04.002.

11. A. Mohammadi, AAfshar, A Etemadi, S Masoudi, ABaghizadeh. Diagnostic value of cross-sectional area of median nerve in grading severity of carpal tunnel syndrome. Arch Iran Med, 2010, pp 516-521. PMID: 21039008

12. RS Martins, MG Siqueira, H Simplicio, D Agapito, M Medeiros. Magnetic resonance imaging of idiopathic carpal tunnel syndrome: correlation with clinical findings and electrophysiological investigation. ClinNeurolNeurosurg, 110 2008, pp 38-45. PMID: 17920190 DOI: 10.1016/j.clineuro.2007.08.025

13. Ikeda M, Okada M, Toyama M, Uemura T, Takamatsu K, Nakamura $\mathrm{H}$. Comparison of median nerve cross-sectional area on 3-T MRI in patients with carpal tunnel syndrome. Orthopedics, 2017. DOI: 10.3928/01477447-20160915-04 PMID: 27648575

14. Kim S, Choi Y, Huh YM. Role of magnetic resonance imaging in entrapment and compressive neuropathy - What, where and how to see the peripheral nerves on the musculoskeletal magnetic resonance image: part 2, Upper extremity. European Radiology, vol 17, no 2, 2007. PMID: 16572333, DOI: 10.1007/s00330-0060180-y

15. Hersh B, D'Auria J, Scott M, Fowler JR. A Comparison of ultrasound and MRI measurements of the cross-sectional area of the median nerve at the wrist. Hand (N Y), 2019,14(6):746-750. https://doi: 10.1177/1558944718777833 PMCID: PMC6900683 PMID:29799270 